\title{
Natural Science and Technology Terminology in the Sesotho sa Leboa Monolingual Dictionary*
}

\author{
W.M. Mojapelo (mojapelo@up.ac.za) and V.M. Mojela (mojelav@ul.ac.za), \\ Sesotho sa Leboa National Lexicography Unit, University of Limpopo, \\ Turfloop Campus, Polokwane, Republic of South Africa
}

\begin{abstract}
The main purpose of this article is to make a comparative analysis of the structural and the lexical differences between coinage and transliteration, as methods for the acquisition of foreign natural science and technology lexical items, which are meant for inclusion in the Sesotho sa Leboa comprehensive monolingual dictionary, Pukuntšutlhaloši ya Sesotho sa Leboa. With the exception of the multilingual glossaries ('dictionaries' as they are called), which are compiled by the National Language Service of the Department of Arts and Culture, the Sesotho sa Leboa National Lexicography Unit does not at present have any monolingual dictionary specializing in specific subjects like natural science and technology. As a start, the Lexicography Unit decided to include this specialized terminology in the second edition of its comprehensive monolingual dictionary. The main purpose for lemmatizing the natural science and technology terminology is to give these lexical items comprehensive definitions in Sesotho sa Leboa, instead of 'a one word translation definition' as is the case in the bilingual and multilingual dictionaries.
\end{abstract}

Keywords: TRANSLITERATION, COINAGE, COINED LEXICAL ITEM, LOAN WORD, ADOPTIVE, FOREIGN WORD, LEXICOGRAPHY, SOTHOIZED WORD, INDIGENOUS WORD, NATURAL SCIENCE, TECHNOLOGY, COMPOUND WORD, AMBIGUITY

Opsomming: Natuurwetenskaplike en tegnologiese terminologie in die Sesotho sa Leboa eentalige woordeboek. Die hoofdoel van hierdie artikel is om ' $n$ vergelykende ontleding te maak van die strukturele en die leksikale verskille tussen nuutskepping en transliterasie as metodes vir die verwerwing van vreemde natuurwetenskaplike en tegnologiese leksikale items wat bedoel is vir insluiting in die Sesotho sa Leboa omvattende eentalige woordeboek Pukuntšutlhaloši ya Sesotho sa Leboa. Met die uitsondering van die meertalige woordelyste ("woordeboeke" soos hulle genoem word) wat deur die Nasionale Taaldiens van die Departement Kuns en Kultuur saamgestel word, het die Sesotho sa Leboa Nasionale Leksikografie-eenheid op die oomblik geen eentalige woordeboek wat spesialiseer in spesifieke onderwerpe soos die natuurwetenskap en tegnologie nie. As ' $n$ begin het die Leksikografie-eenheid besluit om hierdie gespesialiseerde terminologie in die tweede uitgawe van sy omvattende eentalige woordeboek in te sluit. Die hoofdoel vir die lemmatisering van hierdie natuurwetenskaplike en tegnologiese ter-

* An earlier version of this article was presented as a paper at the Twelfth International Conference of the African Association for Lexicography, organized by the Tshwane University of Technology in collaboration with the IsiNdebele National Lexicography Unit, at the Soshanguve Campus, Pretoria, Republic of South Africa, 27-29 June 2007.

Lexikos 19 (AFRILEX-reeks/series 19: 2009): 436-445 
minologie is om hierdie leksikale items omvattende definisies in Sesotho sa Leboa te gee in plaas van " 'n eenwoordvertalingdefinisie" soos die geval is in die tweetalige en meertalige woordeboeke.

Sleutelwoorde: TRANSLITERASIE, NUUTSKEPPING, NUUTGESKEPTE LEKSIKALE ITEM, LEENWOORD, ONTLENING, VREEMDE WOORD, LEKSIKOGRAFIE, VERSOTHODE WOORD, INHEEMSE WOORD, NATUURWETENSKAP, TEGNOLOGIE, SAMESTELLING, DUBBELSINNIGHEID

\section{Introduction}

The main objective of this article is to analyze the structural and the lexical differences between the natural science and technology terms adopted through coinage and transliteration in Sesotho sa Leboa or Northern Sotho. Most of the examples of the science and technology terms used for comparative analysis in this article are derived from the publication of the National Language Services of the Department of Arts and Culture, i.e. the Multilingual Natural Science and Technology Dictionary for Grades $4 \mathcal{E} 6$ (2005). The lemmatization of this terminology in the Sesotho sa Leboa Monolingual Dictionary is aimed at giving the terms full and detailed monolingual definitions, instead of single translation definitions, as those appearing in this word list. The Sesotho sa Leboa natural science and technology terms are mostly derived from foreign languages, especially Latin, Greek, English and Afrikaans, and usually enter the Sesotho sa Leboa lexicon through coinage or transliteration. Coinage is possible where the equivalent indigenous lexical items exist in Sesotho sa Leboa and where lexical items, including loan lexical items, are used as compound words to refer to new concepts. Most natural science and technology terms do not have equivalents in Sesotho sa Leboa, and in these cases, transliteration is used to form new lexical items for the new concepts.

\section{Coinage and transliteration}

Most Sesotho sa Leboa linguistic scholars and theorists prefer the coinage system in formal situations, especially in formal writings and publications. This preference is based on the conviction that the indigenous languages are capable of providing indigenous equivalents for the newly acquired science and technology concepts. For example, the research by Nong, De Schryver and Prinsloo (2002: 17) reveals the following:

By studying the respondents' comments as a whole, it is clear that they prefer the (more) indigenous words to be treated in dictionaries, and that loan words should only be used if there is no good alternative in Northern Sotho. Quite a number of respondents even suggest that words should be coined in order to have a Northern Sotho word instead of an adoptive from other languages. Where offered a direct borrowing and a (Sothoised) loan as only options, the 
(Sothoised) loan is preferred to the direct borrowing. This thus suggests the following preference hierarchy: indigenous word $>$ Sothoised loan word $>$ direct borrowing.

According to this point of view, the best way to develop the vocabulary of the language is to promote or to elevate the indigenous lexical item by widening its scope of reference to refer also to the newly developed science and technology concept.

The Longman Modern English Dictionary defines 'coinage' as the inventing of new words, phrases or expressions. This type of linguistic borrowing is sometimes referred to as neologism, i.e. where only the meaning of the word is adopted and not the word itself. The meaning of the foreign term (the science and technology term) is associated with an indigenous word, especially a word referring to a more or less related sense. The meaning of the indigenous word is extended to include, also, the meaning of the foreign term. The following are examples of lexical items which originated through coinage, and which are listed in the Multilingual Natural Science and Technology Dictionary:

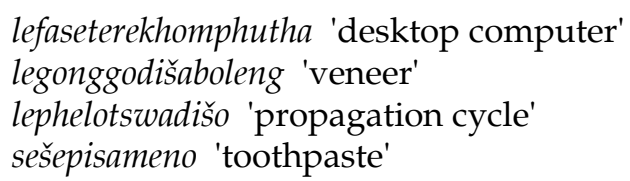

According to the Longman Modern English Dictionary, transliteration is the replacement of the letters of one alphabet by the letters of another alphabet with the same phonetic sounds. The Encarta Concise English Dictionary defines 'transliterate' as:

To represent letters or words written in one alphabet using the corresponding letters of another.

The following are examples of transliterated lexical items taken from the Multilingual Natural Science and Technology Dictionary:

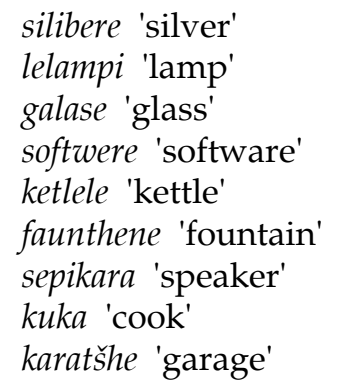

The lexical and structural comparison between the coined and the transliterated lexical items is based on the following factors: ambiguity, increase in vocabulary, compounding, and user-friendliness. 


\section{Ambiguity}

Ambiguity is one of the major factors underlying the differences between the coined and the transliterated lexical items. It is defined by many linguists, lexicographers and semanticists. According to the Longman Modern English Dictionary, ambiguity is:

The quality of having more than one meaning: an idea, statement or expression capable of being understood in more than one sense.

Kooij (1971: 7) points out that a sentence is inherently ambiguous when it sounds the same but has more than one meaning. With regard to ambiguity, Hurford and Heasley (1983: 122) say:

A word or phrase is said to be ambiguous if it has two, or more, synonyms that are not themselves synonyms of each other.

Mojela (1991: 26) mentions that:

Ambiguity is found where a loan word is used synonymously with an indigenous Northern Sotho word to refer to one and the same referent.

The major challenge facing lexicographers in the lemmatization of coined lexical items is their definition. When compared to the lexical items created through transliteration, the definitions of the coined science and technology terms in the Sesotho sa Leboa monolingual dictionary are more complicated. These complications are due to the fact that almost all the coined lexical items are basically ambiguous, i.e. 'have two, or more, synonyms that are not themselves synonyms of each other' (Hurford and Heasley 1983: 122). Adoption of science and technology terms into the Northern Sotho vocabulary through coinage occurs through:

(a) Extending or widening the meaning of existing lexical items to refer also to the meaning of the new terms and, therefore, causing them to become ambiguous, e.g.

mogala: Basic meaning: 'a rope (used to tame cattle or heifers)'

Extended meaning: 'telephone'

(b) Converting the action, function or meaning of the foreign term into a newly coined lexical item, usually in the form of a compound word, to name the new concept, e.g.

sellathekeng: Literally: 'that which cries at the waist'

Meaning: 'cellular telephone'

seoketšamodumo: Literally: 'that which increases sound'

Meaning: 'amplifier' 
In contrast to the preceding coined lexical items which are characterized by ambiguity, i.e. having more than one meaning, the transliterated lexical items are formed by adaptation of the foreign words themselves to the morphological and the phonological system of Sesotho sa Leboa. The transliterated lexical items are usually characterized by having the same meaning as their foreign counterparts, as shown in the following examples:

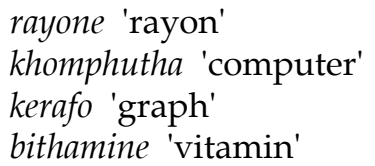

\section{Increase in vocabulary}

The second major difference between coinage and transliteration as important methods of foreign acquisition in Sesotho sa Leboa, is that coinage does not directly lead to an increase in the quantity of lexical items as is the case with transliteration. The reason for this is that in coinage one word is repeatedly used polysemously to refer to several concepts instead of adding new lexical items to the vocabulary. Transliteration leads to an increase in the quantity of lexical items in Sesotho sa Leboa, while coinage only increases the meanings of existing lexical items in the language. The lexicographer will enter the coined lexical item in the monolingual dictionary as a polysemous lexical item, i.e. 'as an instance where a lexical item has a set of more than one, different but related meanings' (Mojela 1991: 31). But the loan lexical item which originated through transliteration in Sesotho sa Leboa is entered in the monolingual dictionary as a new and independent lexical item, therefore increasing the vocabulary of the language instead of only increasing the semantic system of the existing lexical items. The following are examples of differences in the dictionary entries of the coined and the transliterated lexical items in the Sesotho sa Leboa monolingual dictionary:

\section{Coinage:}

\section{mosebe ('arrow')}

1. Sebetša goba sedirišwa sa go dirwa ka tshipi goba motato seo se šomišwago go hlaba goba go bolaya, kudukudu se šomišwa ke batsomi ge ba tsoma diphoofolo goba madira ge a le ntweng.

('A weapon or an instrument, made from steel or wire, which is used to stab or to kill, especially used by hunters when hunting animals or by soldiers during war.')

2. Misaele goba mosebe wa mollo wo o šomišwago ke madira dintweng tša selehono.

('A missile or firearm which is used by soldiers in modern warfare.') 
Transliteration:

misaele ('missile')

Sebetša sa go bopega bjalo ka mosebe se se tlabaketšwego ka dithuthupiši seo se šomišwago ke madira dintweng tša selehono. Sebetša se se rethwa go tšwa sekepeng sa ntwa, sefofane goba go tšwa go setlabakelo sa go thuntšha se se theilwego ka nepo ya go thuntšhetša sebetša se fao se tlago thuthupa se le gona. ('An arrow-like explosive weapon used by soldiers in modern warfare. This weapon is shot from a naval boat, military aircraft or a special instrument designed to fire and direct this weapon where it is required to explode.')

The preceding examples show the following differences between mosebe 'an arrow' (coinage) and misaele 'missile' (transliteration), i.e.:

mosebe: One polysemous lexical item referring to two senses, i.e. (1) an indigenous weapon and (2) a modern military weapon:

mosebe (1) 'arrow' (2) 'missile'

misaele: One transliterated lexical item which bears the basic meaning of its original English source term:

misaele 'missile'

These examples also show that when compared to transliteration, word coinage whose most important feature is polysemy, does not contribute much to the increase of the vocabulary of Sesotho sa Leboa but only of the meaning of existing lexical items in the language. The lexical item, mosebe 'arrow' is entered in the dictionary as one polysemous lexical item even though its reference has been extended to include the newly acquired scientific meaning of a weapon, i.e. 'a missile', while the transliterated lexical item, misaele 'missile', is a new addition to the Sesotho sa Leboa lexicon because the term has never existed before in its vocabulary.

\section{Compounding}

The use of compound lexical items is one of the distinctive features of coined lexical items. Most coined lexical items referring to science and technology concepts are usually descriptive compound words, since the lexical item is derived from the meaning of the foreign term and not from the term itself, as shown in the following examples:

segodišamodumo 'amplifier' Literally: 'that which increases sound' sefatanagantefe 'taxi' Literally: 'motor-car pay me' sehlapišameno 'toothbrush' Literally: 'that which washes teeth' tankaserwaladiela 'tanker' Literally: 'tank which carries liquid' phelakadingwe 'parasite' Literally: 'live on/by others' 
seelakgokaganya mohlagase 'electrolyte' Literally: 'electricity linkage current' moriti wa senepe 'film negative' Literally: 'shadow of photograph'

Here compounding is usually the result of a combination of verbs, substantives and qualificatives to form new compound lexical items which describe the actions or the meanings of the newly acquired or adopted science and technology terms. Most of these newly coined terms are usually long and ambiguous.

The compound lexical item, segodišamodumo, referring to an amplifier, which is an audio device used to increase the volume of sound, consists of a deverbative noun segodiša- 'that which causes to increase', which is derived from the verb stem -godiša- 'cause to increase' and a noun -modumo 'sound'. This is the case also with the coinage sefatanagantefe 'taxi', which is a compound word consisting of the noun sefatanaga- 'car' and -ntefe 'pay me'. The word sefatanaga 'car' is furthermore a compound adopted and standardized earlier, consisting of a deverbative substantive sefata- 'that which ploughs the ground' (derived from -fata- 'plough'), and a noun -naga 'field'.

The compound lexical item sehlapisameno 'toothbrush' literally means 'that which washes the teeth', consisting of a deverbative noun sehlapisa-, derived from the verb stem -hlapa- 'wash', and the noun -meno 'teeth'. The compound tankaserwaladiela 'tanker' literally means 'the tank which carries liquids/fluids', consisting of the noun tanka-, a loan word from English 'tank', a deverbative noun -serwala- from the verb stem -rwala- 'carry' and the deverbative noun -diela 'liquids' or 'fluids' from the verb stem -ela 'flow'. In this case, -serwala- serves as a conjunctive between the two nouns tanka- and-diela.

The lexical item phelakadingwe, which literally means 'live by/on others', refers to a parasite. It is a compound consisting of a verb stem phela-, 'live', an instrumental prefix, $-k a-$ 'with', and a substantive, -dingwe, 'others'. Despite the fact that this compound lexical item is descriptive, its reference can only be understood when used in context. As such, it is too ambiguous when compared to the transliterated loan lexical item, pharasaete 'parasite', as demonstrated in the following sentences:

Ke phelakadingwe:

1. 'It is that which lives on/by others/other things' (which may not necessarily be a parasite)

2. 'It is a parasite'

Ke pharasaete: 'It is a parasite' (which has a direct meaning)

Seelakgokaganya mohlagase 'electrolyte' and moriti wa senepe 'film negative' are multiword lexical items, each one serving as a single grammatical unit. Seelakgokaganya mohlagase which literally means 'electricity linkage current', consists of a deverbative noun seela- 'current' from the verb stem -ela 'flow', a verb stem -kgokaganya- 'link' and the noun -mohlagase 'electricity'. Moriti wa senepe refers to 'film negative', literally meaning 'shadow of a snap/photograph'. It consists of a noun moriti- 'shadow', a possessive concord - $w a-$ 'of' and a noun -senepe 
'photograph' which is a loan word from English 'snap'.

In order to name the newly acquired science and technology concepts, the coinage system is also characterized by the compounding of transliterated lexical items or a combination of loan lexical items and the indigenous lexical items to form new compounds. This is contrary to the preference of most linguistic and indigenous scholars who favour coinage instead of transliteration as a means of foreign acquisition, i.e. the preference of using indigenous terms or indigenous meanings instead of converting the foreign terms to name the newly acquired science and technology concepts. Lexical items such as the following are examples in this regard:

motšheneatšhelete 'ATM (automatic teller machine)'

thelebišenitherei 'plasma television'

lefaseterekhomphutha 'desktop computer'

The coined word motšheneatšhelete referring to an ATM (automatic teller machine) is a compound consisting of two loan words, which are both derived directly from foreign terms, i.e. motšhene- 'machine' (noun), $-a$ - possessive concord (conjunction), and -tšhelete 'money' (noun, from Afrikaans geld). Instead of coining a new, long and ambiguous lexical item by combining foreign lexical items to refer to the ATM, it would have been convenient to consider creating a new loan lexical item from this acronym through transliteration, e.g. eithieme (from the pronunciation of the term). This new creation will not only be an addition to the vocabulary of the language, but will also have a direct meaning when compared to the coined lexical item motšheneatšhelete which can be interpreted or translated to mean 'any machine associated with money', such as a till, a cash, a minting, or a money-counting machine. The suggested transliterated lexical item, eithieme, will refer only to an ATM.

This is also the case with the coined lexical item thelebišenitherei 'plasma television' which consists of two foreign lexical items which were adopted into Sesotho sa Leboa through transliteration, i.e. thelebišeni- from 'television' and -therei from 'tray'. This compound expresses the sense that 'a plasma television' is a television which is shaped like a tray.

The lexical item lefaseterekhomphutha, referring to a desktop computer, is a combination of the following loan lexical items: lefasetere- 'window' (from Afrikaans venster) and -khomphutha 'computer'. Both the lexical items, i.e. lefasetere and khomphutha, are loan lexical items, and another loan lexical item can still be formed through the transliteration of 'desktop', e.g. deskethopho, which will not only be an addition to the Sesotho sa Leboa lexicon, but will also have the direct and unambiguous meaning 'desktop computer'.

\section{User-friendliness}

In comparison with the transliterated lexical items, the coined lexical items are not as user-friendly. Improvements in the knowledge and pronunciation of 
foreign languages, especially English and Afrikaans, the two former official languages of the Republic of South Africa, led to improvements in the pronunciation of foreign lexical items among the Basotho ba Leboa communities. As a result, the transliterated lexical items came to be preferred above the coined lexical items since users opt for words which are closer to the source language and which have meanings equivalent to the original foreign terms. Ambiguity and compounding are among the major factors causing user-unfriendliness as far as coined lexical items are concerned. Ambiguity means that speakers will always have to explain the coined terms in sentences for listeners to understand their meaning. For instance

(1) Ke hlapa meno ka kholkeiti 'I clean my teeth with colgate', instead of: Ke hlapa meno ka sešepisameno 'I clean my teeth with toothpaste/ soap for the teeth'.

The reason for this preference is that the lexical item kholkeiti is a direct equivalent to its original English counterpart, the trade name 'Colgate', when compared to the long, compound and ambiguous coined lexical item, sešepisameno, which consists of the following components: sešepi- 'soap' (noun, loan word from Afrikaans seep), -sa- 'of' (possessive concord), and -meno 'teeth' (noun).

Besides referring to toothpaste, this lexical item can refer to any soap-like cleansing agent for the teeth. However, kholkeiti will always mean 'toothpaste'.

(2) Ke butše deskthopho ya khomphutha ya gagwe 'I opened his/her desktop computer', instead of:

Ke butše lefaseterekhomphutha ya khomphutha ya gagwe 'I opened his/ her desktop computer

The transliterated word deskthopo is not only short and direct to the point, but has an equivalent meaning with the original word 'desktop', while the coined word lefeseterekhomphutha is very long and ambiguous, as explained under section 5 above.

\section{Conclusion}

This article has compared the user-friendliness of the coined and the transliterated natural science and technology terminology in Sesotho sa Leboa. The example terms have been derived from the Multilingual Natural Science and Technology Dictionary. This comparative analysis has revealed the following:

- The majority of scholars and theorists prefer to use the coined lexical items in formal publications and written language, even though they never use most of these lexical items in practical situations.

- The coined lexical items are not user-friendly, due to ambiguity and compounding. 
In comparison to the transliterated lexical items, the lemmatization of the coined lexical items is usually a challenge due to the ambiguity and compounding, as in the following:

(a) In a compound word, the lexicographer will have to be conversant with the etymology for all the components in a compound lexical item in order to give a coined lexical item a complete and accurate lexicographic definition.

(b) Most coined lexical items are entered into the dictionary as polysemous words, i.e. as one word referring to more than one related meaning (therefore ambiguous), while transliterated lexical items always refer to the same meaning as that of the source term in the foreign language (therefore unambiguous).

(c) Some of the coined compound lexical items are very long, and to enter them as lemmata into the dictionary is less convenient than lemmatizing a transliterated lexical item.

\section{References}

Department of Arts and Culture. 2005. Multilingual Natural Science and Technology Dictionary for Grades 4 to 6. National Language Service.

Hurford, J.R. and B. Heasley. 1983. Semantics: A Course Book. Cambridge: Cambridge University Press.

Kooij, J.G. 1971. Ambiguity in Natural Languages. Amsterdam: North-Holland Publishing Company. Mojela, V.M. 1991. Semantic Changes Accompanying Loan-words in the Northern Sotho Lexicon. Unpublished M.A. Dissertation. Pretoria: Vista University.

Nong, S., G.-M. de Schryver and D.J. Prinsloo. 2002. Loan Words versus Indigenous Words in Northern Sotho - A Lexicographic Perspective. Lexikos 12: 1-20.

Rooney, K. (Ed.-in-Chief). 2001. Encarta Concise English Dictionary. London: Bloomsbury.

Watson, O. (Ed.). 1976. Longman Modern English Dictionary. Harlow: Longman. 